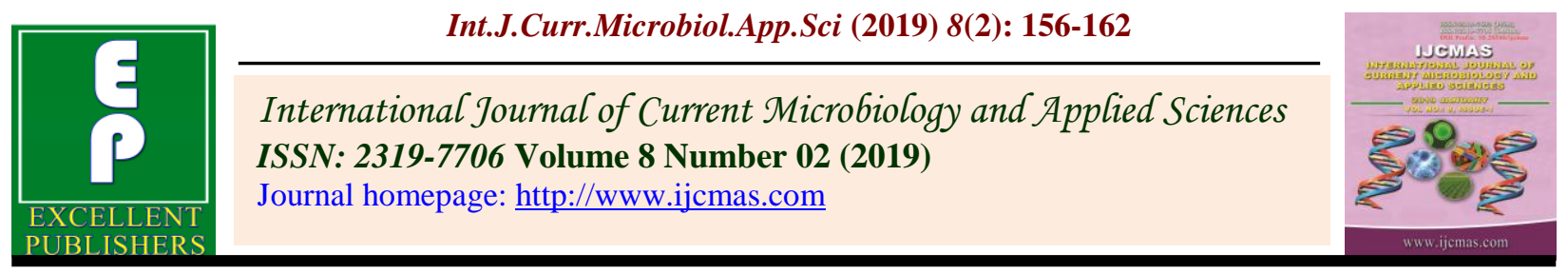

\title{
Performance of Turmeric (Curcuma longa L.) Genotypes for Growth and Yield under High Altitude and Tribal Zone of Andhra Pradesh
}

\author{
S. Vamshi Krishna ${ }^{1 *}$, V. Sivakumar ${ }^{2}$, K. Umajyothi ${ }^{3}$, \\ A.V.D. Dorajeerao ${ }^{3}$ and K. Umakrishna ${ }^{3}$ \\ ${ }^{1}$ Department of Plantation, Spice, Medicinal and Aromatic crops, Bidan Chandra Krishi \\ Vishwavidyalaya, Mohanpur, Nadia, West Bengal, 741252, India \\ ${ }^{2}$ Dr.YSR Horticultural University, Chintapalli-531111, Andhra Pradesh, India \\ ${ }^{3}$ Dr.YSR Horticultural University Venkataramannagudem, West Godavari Dist, Andhra \\ Pradesh, India \\ *Corresponding author
}

\begin{abstract}
A B S T R A C T
Keywords

Evaluation,

Turmeric, Growth,

Yield, High

Altitude and Tribal

Zone

Article Info

Accepted:

04 January 2018

Available Online:

10 February 2019

The present experiment in turmeric was carried out in Randomized Block Design with three replications during Kharif 2017 at Horticulture Research Station, Dr. Y.S.R.H.U, Chinthapalli, Visakhapatnam District. Total nineteen genotypes were evaluated including one national and one local check. Among the genotypes studied, CLA-1 recorded the highest plant height $(169.2 \mathrm{~cm})$, leaf length $(70.53 \mathrm{~cm})$, CLA-5 recorded the highest number of tillers per plant (3.33), var. Roma recorded the highest leaf width $(17.68 \mathrm{~cm})$, var. BSR-2 recorded the highest number of leaves per plant (18.33) and highest leaf area $\left(13454.61 \mathrm{~cm}^{2}\right)$. The maximum yield per plot was observed in CLA-3 $(15.10 \mathrm{~kg})$, whereas the minimum was recorded in CLA-10 $(8.04 \mathrm{~kg})$. The maximum estimated fresh rhizome yield per hectare was recorded in CLA-3 (50.35 t) and the lowest estimated fresh rhizome yield was recorded in the genotype CLA-10 (26.80 t) when compared to other genotypes under HAT zone conditions.

\section{Introduction}

Turmeric (Curcuma longa L.) is one of the important spice and also condiment crops grown in India since times immemorial. It is regarded as a symbol of well being and widely used in ceremonies and religious functions. It is an erect, herbaceous perennial belonging to the family Zingiberaceae and native to South East Asia. Turmeric of commerce is the dried underground rhizome,

valued for its deep yellow colour and pungent aromatic flavour due to the presence of colouring matter "Curcumin" and a volatile oil "termerole". It is also an important condiment which finds a unique place in culinary arts and as colouring agent in textile, food, confectionary, cosmetics and drug industries in the preparation of anticancer medicines.

Turmeric is either grown as a pure crop or inter/mixed crop in coconut, areca nut and
\end{abstract}


coffee plantations. In India it is being cultivated in more than 20 states in an area of 2.37 lakh ha with an annual production of 11.63 MT and earning 1241.89 crores by exporting 1.16 MT to other countries. In India, it is mainly grown in Telangana, Andhra Pradesh, Odisha, West Bengal, Tamil Nadu, Assam, Maharashtra, Karnataka, Bihar and Kerala. Among these, Telangana occupies 50,000 ha of total area and 2.55 MT of total production of the country. The national productivity of crop is 5 tonnes per hectare. (NHB, 2017-18).

Turmeric is a tropical crop and needs a warm and humid climate with an optimum temperature of 20 to $30^{\circ} \mathrm{C}$ for normal growth and satisfactory production. It thrives best on sandy loam or alluvial, loose, friable and fertile soil rich in organic matter status and having a $\mathrm{pH}$ range of 5.0 to 7.5. Alkaline soil is not suitable for its cultivation. The crop cannot withstand water logging. It grows at all places ranging from sea level to an altitude of $1200 \mathrm{~m}$ above mean sea level. As a rain fed crop turmeric needs a well distributed annual rainfall of 250 to $400 \mathrm{~cm}$ for successful production. It is grown for underground stem called as rhizomes, which are used to impart flavour and colour to foodstuffs after clearing, drying, polishing and powdering. The rhizome contains yellow colouring component curcumin (3-9\%), essential oil (5$9 \%$ ) and oleoresin (3-13\%). Curcumin is gaining more importance in food industries, pharmaceuticals, preservatives and cosmetics. The ban on artificial colour has prompted the use of curcumin as a food colorant. In pharmaceuticals it is valued for the anticancerous, anti-inflammatory, antiseptic, antimicrobial and anti proliferative activities.

Genetic improvement may play a vital role in increasing production, productivity and quality parameters. Performance of any crop depends upon its genetic makeup and climatic conditions of the region under which they are grown. Genotype which performs better in one region may not perform well in other regions due to varying climatic conditions. Hence, it is essential to collect and evaluate genotypes in order to select best genotype for a particular agro-climatic condition. Hence, the present investigation was conducted to find a suitable genotype for high altitude and tribal area of Visakhapatnam.

\section{Materials and Methods}

The experimental site was located in the Horticulture Research Station, Chinthapalli, Andhra Pradesh. The location falls under Agro-climatic zone of High Altitude and Tribal Zone with an average annual rainfall from South-west monsoon of more than 1200 $\mathrm{mm}$, maximum temperature range 17 to 35 ${ }^{\circ} \mathrm{C}$, minimum temperature range from 3 to $24^{\circ} \mathrm{C}$ and is located at an altitude of $933 \mathrm{~m}$ MSL. The geographical situation is $17^{0} .13^{\prime} \mathrm{N}$ latitude and $84^{\circ} .33^{\prime}$ E longitudes. The experiment was laid out in a Randomised Block Design with 19 treatments and 3 replications. The planting was done on raised beds spaced row to row $30 \mathrm{~cm}$ with plant to plant distance of $25 \mathrm{~cm}$ and the net plot size was $3 \times 1 \mathrm{~m}^{2}$. The soil of the experimental field was alluvial and it was endowed with good drainage. Recommended package of practices and plant protection measures were followed to raise a healthy crop.

The observations were recorded for growth and yield parameters viz., plant height $(\mathrm{cm})$, number of tillers and leaves per plant, leaf length and width $(\mathrm{cm})$, leaf area per plant $\left(\mathrm{cm}^{2}\right)$, number of mother, primary and secondary rhizomes per plant, length of the mother, primary and secondary rhizome per plant, yield per plot $(\mathrm{kg})$ and estimated fresh rhizome yield per hectare $(\mathrm{t})$. The data were analysed as per statistical procedure given by Verma et al., (1987). 


\section{Results and Discussion}

In the present investigation, different turmeric genotypes measured at 150 days after planting varied significant variation with regard to plant height, number of tillers per plant, number of leaves per plant, leaf area per plant. Among the cultivars studied, CLA-1 recorded the highest plant height $(169.2 \mathrm{~cm})$ followed by NDH-98 $(155.00 \mathrm{~cm})$, Roma $(151.66 \mathrm{~cm})$ and CLA-5 $(147.6 \mathrm{~cm})$, whereas the lowest plant height was recorded in CLA$12(91.16 \mathrm{~cm})$ followed by CLA-11 (92.83 $\mathrm{cm})$ and CLA-2 $(103.66 \mathrm{~cm})$. The longest leaf was recorded in CLA-1 $(70.53 \mathrm{~cm})$, followed by Roma $(69.90 \mathrm{~cm})$ and BSR-2 $(64.40 \mathrm{~cm})$, whereas the shortest leaf was observed in CLA-12 $(39.17 \mathrm{~cm})$ followed by CLA-14 $(45.40 \mathrm{~cm})$ and CLA-8 (45.67 $\mathrm{cm})$. The maximum number of tillers recorded in CLA5 (3.33) followed by CLA-2 (3.13) and CLA1 (2.86), whereas the lowest number of tillers recorded in NDH-98 (1.00) followed by CLA4 (1.40) and CLA-10 (1.80). In leaf width Roma $(17.89 \mathrm{~cm})$, CLA-11 $(17.88 \mathrm{~cm})$ and CLA-13 $(17.68 \mathrm{~cm})$ were found to be significantly more wider leaves than chinthapalli Local $(17.23 \mathrm{~cm})$. The highest number of leaves per plant was recorded in IISR- Prathibha (19.00) followed by BSR-2 (18.33) and CLA-5 (18.06) and Chinthapalli Local (18.00) and all these were on par with one another.

The lowest number of leaves per plant was recorded in CLA-4 (12.46) followed by CLA10 (13.86) and CLA-3 (14.26) and it was observed that Chinthapalli Local (13703.96 $\mathrm{cm}^{2}$ ) recorded the highest leaf area followed by BSR-2 $\left(13454.61 \mathrm{~cm}^{2}\right)$ and these two were on par with each other (Table 1) under HAT zone conditions. The plant height, increased the number of leaves and leaf area leads to better photosynthesis of carbohydrates and their utilization by way of building up of new cells and thereby higher levels of growth, while the lowest plant height $(91.16 \mathrm{~cm})$ recorded in CLA-12 might be due to uptake of nutrients at lower rate resulted in lower plant growth under HAT zone conditions. Such variations in growth among different cultivars of turmeric were reported by several workers Viz., Anusuya et al., (2004), Jadhav et al., (2009), Deshmukh et al., (2009) and Ravindrakumar et al., (2015) in turmeric grown under different conditions.

The genotype CLA-12 consistently showed poor growth in terms of plant height, number of tillers and number of leaves. Among the rhizome parameters, no significant variation was found with number of mother rhizomes per plant. Significantly higher number of primary rhizomes per plant was found in CLA-5 (7.93) followed by NDH-98 (7.40) and CLA-3 (6.73), whereas the highest number of secondary rhizomes per plant was found in CLA-5 (23.73), followed by CLA-1 (18.53) and CLA-3 (17.33).

The maximum length of mother rhizome was found in NDH-98 $(12.07 \mathrm{~cm})$ followed by CLA-4 $(7.83 \mathrm{~cm})$ and CLA-10 $(7.67 \mathrm{~cm})$. The highest length of primary rhizome was recorded in CLA-7 $(9.47 \mathrm{~cm})$ followed by CLA-10 $(9.40 \mathrm{~cm})$ and CLA-4 $(9.40 \mathrm{~cm})$ and length of secondary rhizome was recorded in CLA-3 $(4.20 \mathrm{~cm})$ followed by CLA-2 (3.87 $\mathrm{cm})$ and CLA-12 (3.40 cm) (Table 2). Considerable variation with respect to yield and yield attributing characters like number of mother rhizomes, length of mother rhizome, number of primary rhizomes, length of primary rhizome, number of secondary rhizomes, length of secondary rhizome per plant was reported and acknowledged with earlier studies of Deshmukh et al., (2009), Chaturvedi et al., (2009), Veena (2012), Siddalingayya et al., (2014), Ravindrakumar et al., (2015) and Mohan et al., (2017). 
Table.1 Mean performance of turmeric genotypes for different plant growth characters

\begin{tabular}{|c|c|c|c|c|c|c|c|}
\hline S. No & Genotypes & $\begin{array}{l}\text { Plant height } \\
\text { (cm) }\end{array}$ & $\begin{array}{c}\text { Number of tillers } \\
\text { per plant }\end{array}$ & $\begin{array}{c}\text { Number of } \\
\text { leaves per plant }\end{array}$ & $\begin{array}{l}\text { Leaf length } \\
\quad(\mathrm{cm})\end{array}$ & $\begin{array}{l}\text { Leaf width } \\
\quad(\mathrm{cm})\end{array}$ & $\begin{array}{c}\text { Leaf area per } \\
\text { plant }\left(\mathrm{cm}^{2}\right)\end{array}$ \\
\hline 1. & CLA-1 & 169.20 & 2.86 & 15.06 & 70.53 & 16.87 & 12887.73 \\
\hline 2. & CLA-2 & 103.66 & 3.13 & 16.06 & 47.49 & 12.63 & 6941.20 \\
\hline 3. & CLA-3 & 107.13 & 2.06 & 14.26 & 46.53 & 13.69 & 6539.24 \\
\hline 4. & CLA-4 & 132.63 & 1.40 & 12.46 & 57.80 & 16.50 & 8483.32 \\
\hline 5. & CLA-5 & 147.60 & 3.33 & 18.06 & 57.00 & 15.19 & 11290.25 \\
\hline 6. & CLA-6 & 141.83 & 1.93 & 16.46 & 60.40 & 14.91 & 10691.59 \\
\hline 7. & CLA-7 & 109.93 & 2.66 & 17.93 & 46.87 & 14.37 & 8690.58 \\
\hline 6. & CLA-8 & 103.92 & 2.86 & 17.93 & 45.67 & 14.71 & 8671.10 \\
\hline 9. & CLA-9 & 103.76 & 2.46 & 17.80 & 46.20 & 14.35 & 8574.82 \\
\hline 10. & CLA-10 & 122.53 & 1.80 & 13.86 & 54.93 & 14.47 & 8037.17 \\
\hline 11. & BSR-2 & 138.06 & 2.60 & 18.33 & 64.40 & 15.93 & 13454.61 \\
\hline 12. & CLA-11 & 92.83 & 2.66 & 16.33 & 47.33 & 17.88 & 9936.89 \\
\hline 13. & CLA-12 & 91.16 & 2.00 & 15.53 & 39.17 & 12.20 & 5362.86 \\
\hline 14. & CLA-13 & 137.13 & 1.86 & 16.60 & 61.60 & 17.68 & 13040.13 \\
\hline 15. & CLA-14 & 114.00 & 2.40 & 16.40 & 45.40 & 12.80 & 6849.75 \\
\hline 16. & NDH-98 & 155.00 & 1.00 & 16.13 & 60.53 & 16.57 & 11753.53 \\
\hline 17. & Roma & 151.66 & 2.26 & 14.60 & 69.90 & 17.89 & 13129.63 \\
\hline 18. & IISR-Prathibha & 140.23 & 2.13 & 19.00 & 60.07 & 15.20 & 12417.09 \\
\hline \multirow[t]{3}{*}{19.} & Chinthapalli Local & 139.42 & 2.53 & 18.00 & 62.00 & 17.23 & 13703.96 \\
\hline & $\mathrm{SE}(\mathrm{m}) \pm$ & 5.12 & 0.29 & 1.34 & 1.68 & 0.72 & 123.42 \\
\hline & $\mathrm{CD}$ at $5 \%$ & 10.44 & 0.60 & 2.74 & 4.84 & 2.08 & 354.00 \\
\hline
\end{tabular}


Table.2 Yield and yield attributing characters of different turmeric genotypes

\begin{tabular}{|c|c|c|c|c|c|c|c|c|c|}
\hline S.NO & Genotypes & $\begin{array}{l}\text { Number } \\
\text { of mother } \\
\text { rhizomes }\end{array}$ & $\begin{array}{c}\text { Length of } \\
\text { mother } \\
\text { rhizome }\end{array}$ & $\begin{array}{c}\text { Number of } \\
\text { primary } \\
\text { rhizomes }\end{array}$ & $\begin{array}{c}\text { Length of } \\
\text { primary } \\
\text { rhizome }\end{array}$ & $\begin{array}{c}\text { Number of } \\
\text { secondary } \\
\text { rhizomes }\end{array}$ & $\begin{array}{c}\text { Length of } \\
\text { secondary } \\
\text { rhizome }\end{array}$ & $\begin{array}{c}\text { Yield } \\
\text { per plot } \\
(\mathbf{k g})\end{array}$ & $\begin{array}{l}\text { Estimated fresh } \\
\text { rhizome yield } \\
\text { per ha (t) }\end{array}$ \\
\hline 1. & CLA-1 & 1.40 & 7.33 & 5.73 & 7.60 & 18.53 & 2.73 & 10.87 & 36.24 \\
\hline 2. & CLA-2 & 1.93 & 5.90 & 5.80 & 9.13 & 13.20 & 3.87 & 11.24 & 37.49 \\
\hline 3. & CLA-3 & 1.73 & 5.73 & 6.73 & 9.20 & 17.33 & 4.20 & 15.10 & 50.35 \\
\hline 4. & CLA-4 & 1.40 & 7.83 & 4.53 & 9.40 & 12.40 & 3.07 & 8.43 & 28.10 \\
\hline 5. & CLA-5 & 1.47 & 7.40 & 7.93 & 9.23 & 23.73 & 3.20 & 14.54 & 48.49 \\
\hline 6. & CLA-6 & 1.67 & 7.00 & 5.77 & 8.13 & 12.73 & 3.07 & 8.56 & 28.55 \\
\hline 7. & CLA-7 & 1.87 & 5.80 & 5.43 & 9.47 & 13.67 & 3.30 & 12.15 & 40.52 \\
\hline 6. & CLA-8 & 1.53 & 5.53 & 5.13 & 8.33 & 11.00 & 3.38 & 9.51 & 31.70 \\
\hline 9. & CLA-9 & 1.53 & 5.03 & 5.60 & 8.20 & 15.27 & 2.80 & 10.17 & 33.90 \\
\hline 10. & CLA-10 & 1.37 & 7.67 & 5.10 & 9.40 & 10.20 & 2.80 & 8.04 & 26.80 \\
\hline 11. & BSR-2 & 1.60 & 6.47 & 5.47 & 8.67 & 16.27 & 3.20 & 9.17 & 30.56 \\
\hline 12. & CLA-11 & 1.47 & 5.77 & 4.37 & 9.33 & 7.80 & 3.37 & 8.39 & 27.97 \\
\hline 13. & CLA-12 & 1.53 & 4.80 & 5.33 & 9.00 & 12.40 & 3.40 & 10.33 & 34.44 \\
\hline 14. & CLA-13 & 1.80 & 6.23 & 4.93 & 7.90 & 12.73 & 3.20 & 10.47 & 34.92 \\
\hline 15. & CLA-14 & 1.53 & 6.00 & 4.93 & 8.67 & 13.60 & 3.20 & 9.35 & 31.19 \\
\hline 16. & NDH-98 & 1.00 & 12.07 & 7.40 & 7.47 & 15.67 & 2.83 & 10.99 & 36.65 \\
\hline 17. & Roma & 1.60 & 6.87 & 5.87 & 8.07 & 14.93 & 3.00 & 8.76 & 29.21 \\
\hline 18. & $\begin{array}{l}\text { IISR- } \\
\text { Prathibha }\end{array}$ & 1.87 & 6.97 & 6.00 & 8.60 & 14.00 & 2.93 & 8.65 & 28.84 \\
\hline 19. & $\begin{array}{l}\text { Chintapalli } \\
\text { Local }\end{array}$ & 1.20 & 6.20 & 5.60 & 8.13 & 13.93 & 2.87 & 7.71 & 25.86 \\
\hline & $\mathrm{SE}(\mathrm{m}) \pm$ & 0.17 & 0.30 & 0.38 & 0.39 & 0.59 & 0.28 & 0.93 & 3.10 \\
\hline & $\mathrm{CD}$ at $5 \%$ & NS & 0.86 & 1.09 & 1.14 & 1.69 & N.S & 2.70 & 8.94 \\
\hline
\end{tabular}


Higher production of mother, primary and secondary rhizomes may be due to better growth and vigour in some genotypes, as a result yield might be highly influenced by these traits. The rhizome growth was also attributed to better absorption of nutrients from the soil.

The maximum yield per plot was observed in CLA-3 (15.10 kg), whereas the minimum was recorded in CLA-10 (8.04 kg). The maximum estimated fresh rhizome yield per hectare was recorded in CLA-3 (50.35 t), which was followed by CLA-5 (48.49 t) and these two were on par with each other. The lowest estimated fresh rhizome yield was recorded in the genotype CLA-10 (26.80 t). It might be attributed to the active photosynthesis favouring accumulation and assimilation of carbohydrates, as this genotype had recorded higher values for plant height, number of leaves and leaf area. These results are in collaborated with the earlier works of Yadav (2002), Pirjade et al., (2007) and Jadhav et al., (2009) in turmeric with regard to the relationship between yield and growth parameters. The yield is governed by genetic and environmental factors and varies with the genotypes which are in collaboration with the findings of Sheshagiri and Uthaiaha (1994). The yield of any crop majorly depends on the vigour of the plant as indicated by various growth parameters like plant height, number of leaves and rhizome characters. The best growth normally results in high yield and is influenced by genetic and environmental factors too under which the crop is grown

From the present investigation it was concluded that among the nineteen genotypes, the maximum yield per plot was observed in CLA-3 (15.10 kg) followed by CLA-5 (14.54 $\mathrm{kg}$ ) whereas the minimum was recorded in CLA-10 (8.04 kg) and for fresh rhizome yield per hectare, CLA-3 (50.35 t), CLA-5 (48.49 t) and CLA-7 (40.52 t) were excelled than both the checks i.e. IISR Prathibha $(28.84 \mathrm{t})$ and Chinthapalli Local (25.86 t),. Hence, these genotypes can be adopted for commercial cultivation after further testing.

\section{References}

Anusuya, N. S, Hanamashetti, S. I. and Hegde, N. K. 2004. Evaluation of different genotypes of turmeric for yield and quality under irrigated condition for command area of Northern Karnataka. Karnataka Journal of Horticulture. 1 (1):111114.

Chaturvedi, O. P, Dwivedi, A. K. and Tripathi, S. M. 2009.Varietal performance of turmeric. The Asian Journal of Horticulture. 4(2): 517-18.

Deshmukh, N. A, Gondane, S. U, Ingole, P. S. and Patil, S. R. 2009. Performance of different promising cultivars of turmeric under Nagpur condition. Journal of Soils and Crops. 19(1):8891.

Jadhav, G. G, Kankal, D. S. and Ganvir, M. M. 2009. Evaluation of turmeric genotypes in relation to growth, yield and quality parameters. Annals of Plant Physiology. 23(2): 204-06.

Mohan, K. A. B, Yogesh, G. S, Navi, S. S, Naresh, N. T. and Chandrakala, H. 2017. Varietal Performance of Turmeric (Curcuma Longa L.) in Chamarajanagar District of Karnataka. Journal of Krishi Vigyan. 6(1): 21720.

NHB, 2017-18. State wise area and production of spices In: Indian Horticulture Board data base, 2016, Ed. Chander, P. Gandi, National Horticulture Board, Ministry of Agriculture and Farmers welfare, Government of India, Gurgaon. (http://www.nhb.gov.in).

Pirjade, F. N, Jogdande, N. D, Nandre, D. R, 
Ghawade, S. M. and Patil, P. A. 2007. Varietal performance of turmeric. Plant Archives. 7(1): 363-64.

Ravindrakumar, K, Narasimha, R. S, and Raja Kumar, N. 2015. Evaluation of turmeric (curcuma longa $\mathrm{L}$.) cultivars at agency areas of north coastal Andhra Pradesh. An International Journal Society for Scientific Development in Agriculture and Technology.10 (4): 2417-420.

Sheshagiri, K. S. and Uthaiah, B. C. 1994. Performance of turmeric (Curcuma longa $\mathrm{L}$.) varieties at the hill zone of Karnataka, India. Journal of Spices \& Aromatic Crops. 3(2): 161-63.

Siddalingayya, S, J. Venkatesha, J, Sudheesh, K. and Raviraja, S.G. 2014. Evaluation of turmeric (Curcuma longa L.) cultivars for growth and yield in southern dry zone of Karnataka. Advance Research Journal of Crop Improvement. 5(2): 162-65.

Veena, H, 2012. Performance of turmeric (Curcuma longa L.) cultivars in hill zone of Karnataka. M.Sc. (Hort) Thesis. University of Horticultural Sciences, Bagalkot.

Verma, R. K, Pandey, V. P, Solankey, S. S. and Verma, R. B. 2014. Genetic variability, character association and diversity analysis in turmeric. Indian Journal of Horticulture. 71(3): 36772.

Yadav, R. K. 2002. Performance of ginger and turmeric genotypes in Raigarh district of Chhattisgarh. Journal of Spices and Aromatic Crops. 11(1): 62-63.

\section{How to cite this article:}

Vamshi Krishna, S., V. Sivakumar, K. Umajyothi, A.V.D. Dorajeerao and Umakrishna, K. 2019. Performance of Turmeric (Curcuma longa L.) Genotypes for Growth and Yield under High Altitude and Tribal Zone of Andhra Pradesh. Int.J.Curr.Microbiol.App.Sci. 8(02): 156162. doi: https://doi.org/10.20546/ijcmas.2019.802.019 